\title{
Introduction: the many faces of the public domain
}

\section{Hector MacQueen and Charlotte Waelde}

This volume is part of the output from the Arts and Humanities Research Council (AHRC) Research Centre for Studies in Intellectual Property and Technology Law at Edinburgh University Law School, under one of its three anchor research themes: 'Intellectual Property, Cultural Heritage and the Public Domain'.

Among the aims of the projects being carried out under this theme are the examination of the history, role and function of the public domain in relation to all areas of intellectual property, together with consideration of the extent to which the public domain may be diminishing with the expansion of intellectual property right claims, and the effect this may have on cultural and scientific production. In particular, there is to be exploration of the implications of digitisation of public domain material for use on the Internet, with particular reference to issues about access, reproduction, commercial exploitation and privacy.

From the beginning of the Centre in 2002 an inter-disciplinary approach to this investigation was thought to be essential. A working group with participants drawn from many different backgrounds met in March 2003 to identify areas crossing over between concepts of public domain and scientific and cultural heritage. The choice of topics for discussion in this book owes much to the deliberations of the working group, and indeed many of the contributors were among the participants on that occasion. One other follow-up to the 2003 meeting was a further meeting, held in September 2004, with another multidisciplinary group to discuss 'An IP-Free World in Higher Education'. ${ }^{1}$ This meeting produced some more of the topics of and contributors to this book, work for which began in earnest shortly afterwards.

The importance of the idea of the 'public domain' in the cultural and scientific contexts is that it is a body of knowledge and information to which there is general access for use for purposes such as education (formal and informal) and

1 A note summarising the discussion and tentative conclusions reached at that meeting is available on the AHRC Centre's website, http://www.law.ed.ac.uk/ahrb. 
the further development of knowledge, understanding, creativity and inventiveness. Great names of the past may be quoted in support of its value: for example, Samuel Taylor Coleridge's version of a famous metaphor, 'The dwarf sees farther than the giant, when he has the giant's shoulder to mount on.' 2 A more down-to-earth metaphor is provided in the present collection by Bill Thompson, speaking on behalf of creative writers, whether of fiction or non-fiction: 'For a writer the "public domain" is ... the mulch on the forest floor of creativity through which we chew our way.' A well-stocked and healthy public domain is therefore crucial, it is said, to ongoing innovation in both the cultural and scientific arenas, at least standing alongside intellectual property's incentive of exclusivity and potential financial reward in pursuit of the same general goal. The arrival of the Internet has given new potency to this idea of a public domain, by making available to all with access to the network an extraordinary array of material in a variety of forms - not quite the sum of human knowledge and experience available at the click of a mouse, but much nearer to that than any time in history, and meanwhile continuing to grow at an exponential rate.

If the public domain is so important, it becomes as important to identify what it is, and what its continued well-being requires, as it is to promote the development and enforcement of intellectual property rights. For lawyers such as our contributors Gillian Davies and Fiona Macmillan, the natural starting point in thinking about ideas of public domain in relation to cultural and scientific knowledge is the law of intellectual property. Indeed, as Willem Grosheide observes, in the medieval and early modern world before intellectual property, the concept of a general public domain was barely thinkable. The great Renaissance scholar Erasmus of Rotterdam might say around 1500 that 'friends hold all things in common', but the circle of friends in a world before printing, mass literacy and readily accessible communications technology was a very limited one. One of the earliest appearances of the phrase 'public domain' in a legal setting is found in Article 18 of the Berne Convention for the Protection of Literary and Artistic Works 1886, referring to the position of works the copyright in which has expired. Public domain analysis in law really begins from the identification of whatever it is that lies unprotected by intellectual property rights and so is free for use by all engaged in intellectual endeavours of whatever kind, being incapable of that exclusivity which is the core of legal conceptualisations of ownership.

Other forms of property right may also be relevant, or even more important in practical terms: for example, private ownership of personal papers or works of art may be all that is needed to keep such material out of any form of public view or use, regardless of whether or not intellectual property rights are also

2 The Friend, vol. 1, essay 8 (1818). 
involved. However, as another contributor, Antony Taubman, points out, since property and intellectual property laws are fundamentally territorial, varying from jurisdiction to jurisdiction, this means at least that the scope and content of the public domain so defined is also fundamentally contingent upon the facts of legal geography, and not everywhere the same. The starting point for further analysis may therefore be James Boyle's perceptive observation, made in an earlier colloquium on the subject at Duke University in the USA, that we have not one but many public domains ${ }^{3}$ or, perhaps, that the public domain has many different faces according to the place from which it is viewed.

On the evidence of this volume, however, the lawyer's initial perception of the public domain as the opposite of property is often shared by those working in other disciplinary contexts. Thus, from the perspective of creative writers and librarians respectively, Bill Thompson and Toby Bainton see copyright as the key determinant of the public domain. Economists, says Manfredi La Manna, are ill at ease with concepts of the public domain because their most trusted points of reference, such as, well-defined property rights and individual incentives, are missing. In the scientific world Helen Wallace and Susan Mayer see the research agenda as increasingly driven by the pursuit of patents and what is patentable, rather than by global needs in terms of health and food security, particularly those of poor and disadvantaged populations. This does at least point to a different, possibly more political than legal, approach to the public domain, a theme taken up by Ann Bruce when she argues, referring in particular to the GM crops debate, that 'public domain' in relation to science means greater public engagement with, and control of, scientific research, reducing the "private domain' of scientists and expert advisory groups in this area. Bruce sees this form of the public domain expanding now and in the future.

To define the public domain as everything not subject to the claims of property is, however, potentially a serious over-simplification, as Ronan Deazley reminds us in his contribution. It is not, for example, an abuse of language to think of something as being in the public domain which, whatever its intellectual property status, is merely published or even just publicised. Dan Brown's celebrated (or reviled, according to taste) novel The Da Vinci Code is as surely in the public domain as it is in copyright. The sale, gift and loan of millions of copies around the world, together with a major film adaptation and coverage across the media of a sensational court case in London, ${ }^{4}$ have ensured that much of the book's

3 Boyle, J. (2003), 'The Second Enclosure Movement and the Construction of the Public Domain', 66 Law and Contemporary Problems 33.

4 Baigent $v$ Random House Group Ltd [2006] EWHC 719 (Ch). The case also demonstrates the extent to which Dan Brown (and his wife) relied upon what the judge found to be the public domain elements of other copyright works in composing The $D a$ Vinci Code. 
story line, incident and underpinning ideas can be the subject of water-cooler discussions among people around the world, including those who find the whole phenomenon offensive or shocking and as a result refuse to read the book. Even the most aggressive corporate lawyer will recognise that no copyright can stop me, prompted by the curiosity sparked by publicity, idly glancing through, absorbing or confirming knowledge of the contents of, but not buying, The $\mathrm{Da}$ Vinci Code in an airport bookshop while awaiting the calling of my flight. In another realm of intellectual property, one of the points of a patent is the public disclosure of the invention for others to use in their own inventive work even while the patent is still live. James Boyle himself pointed out that such dedications of material to the public domain as the General Public Licence for open-source software and, more generally, Creative Commons licences, nonetheless gain their binding quality from the underpinnings of intellectual property rights in the subject matter. ${ }^{5}$

Further, free use does not necessarily mean simply use for free; or, as Richard Stallman famously put it, free is often better understood as in free speech (or, indeed, freedom) rather than as in free beer. ${ }^{6}$ Gillian Davies refers to, although only to reject, the concept of the 'paying public domain', under which there is a continuing obligation to pay for the use of works after copyright expires, the royalties being collected for the general benefit of living authors or for other cultural purposes. Another possible but different example of this kind of free but paid for use may arise from new European laws requiring public bodies to allow the re-use of information gathered by them in the discharge of their public function. But, as explained here by Richard Susskind, Chair of the United Kingdom Cabinet Office Advisory Panel on Public Sector Information, ${ }^{7}$ the copyright which public bodies enjoy in the material they produce allows them a discretion on whether or not to charge, so long as they do so on fair, transparent and equal terms. Antony Taubman shows that a somewhat similar approach is taken by international bodies such as the United Nations with regard to the treaty texts of which they are guardians, and Davies discusses UNESCO policy guidelines on the development and promotion of governmental information, issued in 2004, that accept such use of public body intellectual property rights while also encouraging permissive licences or waivers. ${ }^{8}$ There is, of course, an important contrast here with the position in the United States, where publicly produced information (such as mapping and weather data) is outside copyright

5 Boyle (2003), 'Second Enclosure Movement', 44-9, 64-6.

6 See the GNU website, at http://www.gnu.org/philosophy/free-sw.html (last visited 2 July 2006).

7 See for the Advisory Panel its website: http://www.appsi.gov.uk/ (last visited 2 July 2006).

8 Available at http://unesdoc.unesco.org/images/0013/001373/137363eo.pdf. 
and freely available (in all senses) for re-use by anyone wishing to do so; public domain, in other words, in the fullest possible way.

Most of our contributors, however, see the public domain as indeed under threat as a result of the modern development of intellectual property law, especially copyright, and agree that this is not for the good. From the European perspective, the evidence includes the extension of copyright terms in the 1990s, which not only lengthened the protection of works already in copyright but also brought back into copyright works whose protection had lapsed within the previous 20 years. The sui generis database right is seen as extending legal protection to facts and information, and not just the way in which those facts are expressed. In patent law, the scope of protection for the products of biotechnology and the software industry has expanded significantly despite the apparent limitations of the European Patent Convention 1973, although there has been so far successful resistance to the United States extension of patentability to business methods. There may be anxiety, apparent in the contributions by Macmillan and by Wallace and Mayer in particular, that as a result of these and other developments the public domain is being appropriated by commercial and corporate interests whose care is only for present profit and not the general good.

A number of contributors also take note of the way in which copyright law now lends support to the technological protection measures (TPMs) and digital rights management (DRM) systems with which right-holders and producers surround their digital and Internet products, to ensure that would-be users pay for their use. This appears to be at least a threat to the public domain, in as much as TPMs and DRM may bar free uses which copyright law would allow - reproduction which is fair dealing for purposes of non-commercial research or private study, for example - or even the use of material no longer or never in copyright. So the public domain possibilities of the Internet are, or may be, stunted and even cut off.

So, if the public domain is a good thing but under threat of diminution or even extinction in places, what is to be done about it? Discussion in the United States has called for an affirmative approach to the public domain: that, instead of defining it principally by reference to what it is not, the concept should be given a positive role in the law. ${ }^{9}$ At its simplest, this might amount to saying that everything is in the public domain save that which is covered by claims of individual or intellectual property. While that might not seem to change very much, it would support arguments that where new intellectual property rights

9 See generally the proceedings of the Duke University Conference on the Public Domain (2003) published in 66 Law and Contemporary Problems; see also Lange, D. (1981), 'Recognizing the Public Domain', 44 Law and Contemporary Problems 147; Litman, J. (1990), 'The Public Domain', 39 Emory LJ 965. 
were under discussion the burden of proof of benefit should lie on the proponents of the new rights. It might mean that rules currently allowing reproduction for certain kinds of fair dealing in relation to such public goods as education, research and news reporting could be transformed from 'copyright exceptions and limitations', useful only as defences to claims of infringement, into user rights, capable of enforcement against those who might deny them through contracts made with the help of TPMs or DRM. And proposals for the solution of practical difficulties often created by the existence of uncertain intellectual property rights - for example, the problem of 'orphan works', discussed by Bainton - would be shaped by a presumption of policy that favoured the easiest possible transition of the material into the public domain.

Some of this reflects the approach of the Royal Society of Arts Adelphi Charter on Creativity, Innovation and Intellectual Property which was launched in London in October 2005. ${ }^{10}$ John Howkins, who chaired the group which produced the Charter, argues here that the fundamental goal of policy should be the promotion of what he calls the creative economy: not just the creative industries, but all players in creativity and invention. ${ }^{11}$ In this view, intellectual property law has its place as a means of regulating the creative economy, with three factors being taken into account: access, use and reward. Laws on intellectual property should be seen as means of achieving these social, cultural and economic goals. Human rights such as the rights to health, education and free expression, as Macmillan too argues, also have a major role to play in reshaping, if not the public domain itself, the ways in which we approach and understand it. Macmillan, following the earlier work of Carol Rose, ${ }^{12}$ and supported in the concluding chapter by Charlotte Waelde, also finds potential models for a multilayered public domain in the perhaps unexpected source of Roman law. Concepts of res publicae, res universitatis, res communes, res nullius and res divini juris as forms of non-exclusive property go some way towards meeting the challenge for notions of public domain presented by the 'tragedy of the commons' thesis (that the absence of private property entails over-use and under-investment of the subject matter ${ }^{13}$ ).

Attractive though all this may sound, there are still pitfalls. As Waelde notes, it seems unlikely that Latin rhetoric will sway modern policy-makers, legislators

10 Available at http://www.adelphicharter.org/adelphi_charter.asp (last checked 2 July 2006).

11 See also Howkins, John (2001), The Creative Economy: How People Make Money from Ideas, London: Penguin Books.

12 Rose, C.M. (2003), 'Romans, Roads, and Romantic Creators: Traditions of Public Property in the Information Age', 66 Law and Contemporary Problems 89.

13 Famously stated in Hardin, G. (1968), 'The Tragedy of the Commons', Science, 13 December, 1243. 
or industry, creative or otherwise. Thompson reminds us of another fundamental, also forcefully brought to our attention at the initial seminar from which this collection springs: that not all professional writers are salaried academics; like most other creators, such writers rely on copyright for their living and do not want everything they create to be in the public domain. John Cahir cautions against too ready a use of rights language in relation to the public domain, which, he argues, following Hohfeld's famous analysis, is best expressed in terms of liberties; the public domain is a land of no rights and should remain so. Claims that citizens are being starved of information or having their freedom of expression rights violated as a consequence of copyright and TPMs or DRM are virtually unsupported by even hearsay evidence. On the contrary, the Internet and digital technology more generally have unleashed a flood of high- (and low-) quality information, seemingly impervious to the supposed threats of copyright law allied with self-help exclusionary measures. Graham Dutfield imagines a world without intellectual property rights, deploying counterfactual techniques to analyse historical events. He finds that, although certain developments in pharmaceuticals would have occurred in the absence of patents, there would have been less than we now have. Abolition of drug patents is difficult to argue for realistically, given the high costs of research and development. Likewise copyright reflects something of the way authors see themselves as individuals, and abolition of copyright would be in diminution of that sense of self. Dutfield suggests that we cease to oppose 'rights' and 'no-rights' models, and ask instead what rights we need and what rights we should have.

A particularly telling critique is provided by Johanna Gibson, who discusses the problems which the concept of public domain rights presents for the indigenous knowledge of local and traditional communities around the world (a matter also touched upon by Taubman). This 'traditional knowledge' (TK) was, and to an extent continues to be, interpreted within the discourse of the common heritage of mankind, or public domain; yet this amounts to a justification for appropriation, often directly against the wishes of the community and its perception of its needs and entitlements. For Macmillan, TK may be best seen as res universitatis within the public domain: that is, as a regime bounded by property rights, with a type of limited public domain (or commons) inside those boundaries. But nonetheless the issue shows how culturally specific notions of public domain may cut across or undermine diversity and the identity and cultural integrity of different communities.

The public domain thus does indeed have at least many faces, if it is not in fact plural and diverse; and we are far from understanding what the implications may be for law or policy. But this volume does at least offer a further step towards coming to grips with these questions and defining the boundaries within which debate should be taking place. In so far as the concept aims to support innovation, creativity and invention, it appears to have the same objectives as 
intellectual property rights; and their mutual recognition is therefore surely not out of reach. Perhaps too in this process we need to think a little less of rights and a little more of liberties, freedom and respect for human dignity. Somewhere in that mix we may begin to get the balance a little better and enable the Internet to realise its awesome potential. 